\title{
ANALISIS KEBIJAKAN PENGELOLAAN HUTAN LINDUNG: KEMUNGKINAN PENYADAPAN GETAH PINUS DI HUTAN LINDUNG
}

\author{
(Policy Analysis on Protected Forest Management : The Possibilities to Tap \\ Pine Resin in Protection Forest)
}

\author{
Oleh / By : \\ Subarudi, Ngaloken Gintings, dan Suwardi Sumadiwangsa
}

\begin{abstract}
Moratorium on pine resin extraction has been done by Perum Perhutani due to the forest status changing from production forest to protection forest (around 30\%). This changing has an effect on the decreasing of resin extraction area and the prosperity of local community where the resin extraction activities became their main and secondary livelihood culturally. Therefore, the policy analysis on the possibilities to utilize protection forests for resin extraction is required. The results of analysis indicated that: (1) pine resin extraction in protection forests is categorized as one of forest utilization activities in form of non wood forest product (NWFP) extraction; (2) from legal formal aspect, the resin extraction is permitted and can be carried out only in an utilization block without logging the trees; (3) from technical aspect, the resin extraction is only allowed by using riil method that can not cause felled trees; (4) from land water conservation aspect, the resin extraction is permitted as long as taking into account the factors affecting run off and erosion, such as slope, trees crown, ground crops, soil type, rain fall, mulching, and potential landslide areas; and (5) from implementation aspect, the resin extraction can be conducted by local communities and cooperatives. This implementation is done in the frame of community based forest management (CBFM) with a proportional production sharing between Perhutani and communities.
\end{abstract}

Keywords: Analysis, pine resin extraction, and protection forest management.

\begin{abstract}
ABSTRAK
Penghentian sementara kegiatan penyadapan getah pinus oleh Perum Perhutani karena perubahan status dari hutan produksi menjadi hutan lindung (sekitar $30 \%$ ). Hal ini membawa dampak kepada penurunan luas sadapan getah pinus dan sekaligus kepada kesejahteraan masyarakat sekitar hutan, dimana kegiatan penyadapan ini telah membudaya dan menjadi pekerjaan utama dan sampingan. Oleh karena itu kajian kebijakan tentang kemungkinan pemanfaatan hutan lindung untuk penyadapan menjadi sangat penting. Hasil kajian menunjukkan bahwa: (1) penyadapan getah pinus di Hutan Lindung dapat dikatagorikan sebagai salah satu upaya pemanfaatan hutan dalam bentuk pemungutan hasil hutan bukan kayu (HHBK) oleh masyarakat setempat dengan binaan oleh Perhutani; (2) dari segi yuridis formal, penyadapan getah diperkenankan dan dapat dilakukan hanya pada blok pemanfaatan dengan tidak melakukan penebangan pohon; (3) dari segi teknis penyadapan, penyadapan getah hanya dapat dilakukan dengan metoda penyadapan sersan terbalik (riil method) yang secara teknis tidak akan menyebabkan pohon roboh/rebah; (4) dari segi konservasi tanah dan air, penyadapan getah diperkenankan sepanjang tidak mengabaikan faktor-faktor penyebab terjadinya aliran permukaan dan erosi, seperti lereng lapangan, lapisan tajuk, tanaman bawah, jenis tanah, curah hujan, serasah dan daerah-daerah yang rawan longsor; dan (5) dari segi teknis pelaksanaan, penyadapan getah dapat dilakukan oleh masyarakat atau koperasi. Hal ini tentunya dapat diwujudkan dalam kerangka PHBM dengan sistem bagi hasil yang proporsional antara Perhutani dengan masyarakat.
\end{abstract}

Kata kunci: Kebijakan, penyadapan pinus, dan pengelolaan hutan lindung 


\section{PENDAHULUAN}

Pengelolaan hasil hutan bukan kayu (HHBK) selama 20 tahun terakhir belum mengalami perkembangan yang berarti. HHBK hanya dijadikan slogan belaka tentang betapa pentingnya HHBK karena prospeknya yang cerah dan kemampuannya untuk mendukung pengelolaan hutan lestari (HHBK dipungut tanpa melalui penebangan pohon, kecuali gaharu dan rotan) (Subarudi, 2002).

Perum Perhutani telah dikenal luas sebagai pelopor, pengembang, dan penghasil produk HHBK seperti, madu, lak, kopal, kayu putih, gondorukem dan terpentin. Produk gondorukem dan terpentin adalah hasil proses ekstrasi getah dari batang pohon pinus (Pinus merkusii) yang diperoleh dari kegiatan penyadapan dengan metoda koakan (quarre method) dan metoda $\mathrm{V}$ atau saluran (riil method) yang di Perhutani dikenal dengan metoda "sersan terbalik".

Produksi gondorukem dan terpentine nasional dari tahun 1993/94 sampai tahun 1998/99 adalah 61.285 ton dan 10.869 ton setiap tahunnya. Dalam tahun 19951999 Perum Pehutani mampu memproduksi gondorukem dan terpentin rata-rata per tahun sebesar 64.836 ton dan 12.220 ton dengan tingkat rendemen rata-rata $68,2 \%$ untuk gondorukem dan $18,8 \%$ terpentin. Data ini menujukkan bahwa Perum Perhutani merupakan produsen tunggal untuk kedua produk tersebut (Subarudi, etal., 2001).

Saat ini luas areal sadapan getah pinus di areal Perum Perhutani Unit III Jawa Barat dan Banten (selanjutnya disebut Perhutani) selama lima tahun terakhir terus menerus mengalami penurunan secara signifikan dari luasan 20.942 ha (2000) menjadi 12.848 ha (2004) dengan laju sekitar 1.619 ha/tahun. Penyebab dari turunnya luas sadapan getah pinus disebabkan karena: (i) penghentian penyadapan di beberapa areal hutan produksi yang sudah tidak produktif, dan (ii) penghentian penyadapan karena perubahan status dari hutan produksi menjadi hutan lindung (sekitar 30\%) sebagaimana ditetapkan dalam SK Menteri Kehutanan No. 195/Kpts-II/2003, tanggal 4 Juli 2003 (Perhutani, 2004).

Penurunan luas sadapan getah pinus membawa dampak kepada kesejahteraan masyarakat sekitar hutan, dimana kegiatan penyadapan ini telah membudaya dan menjadi pekerjaan utama dan sampingan. Jika hal ini tidak diantisipasi akan memunculkan kerawanan sosial dan pada akhirnya akan mengancam kelestarian dari pengelolaan hutan. Sejak keluarnya SK Menhut No. 195/2003 Perum Perhutani terus melaksanakan penyadapan getah pinus di areal hutan produksi. Namun di areal hutan produksi yang telah berubah menjadi hutan lindung $(\mathrm{HL})$ telah dihentikan sementara (moratorium) sambil melihat kemungkinan-kemungkinan atau peluang pemanfaatan $\mathrm{HL}$ untuk kegiatan penyadapan bagi masyarakat setempat dari aspek yuridis formal, teknis penyadapan, dan keramahan lingkungan (environmentally friendly).

Oleh karena itu kajian kebijakan pengelolaan $\mathrm{HL}$ untuk kegiatan penyadapan getah pinus sangat diperlukan oleh Perum Perhutani sebagai upaya memperoleh pendapatan (untuk pemeliharaan $\mathrm{HL}$ ) dan membuka kembali lapangan kerja penyadapan sebagai upaya peningkatan penghasilan bagi para mantan penyadap getah di tengah sulitnya mencari lapangan pekerjaan.

Tujuan dari kajian ini adalah untuk mengetahui faktor-faktor yang mempengaruhi kegiatan penyadapan getah pinus dan memberikan rekomendasi yuridis dan teknis dalam memanfaatkan $\mathrm{HL}$ untuk kegiatan penyadapan getah pinus sebagai upaya mencapai kelestarian $\mathrm{HL}$ dan kesejahteraan masyarakat.

Sedangkan sasaran kajian ini adalah:

1. Menganalisis peraturan dan kebijakan dalam pengelolaan $\mathrm{HL}$, khususnya pemanfaatannya untuk kegiatan penyadapan getah pinus. 
2. Memberikan rekomendasi sistem penyadapan getah pinus yang tepat dari segi teknis penyadapan dan lingkungan (konservasi tanah dan air).

3. Memberikan alternatif pengelolaan hutan bersama masyarakat (PHBM) dalam pelaksanaan penyadapan getah pinus di $\mathrm{HL}$.

\section{METODOLOGI}

\section{A. Kerangka Pemikiran}

Pola pikir yang digunakan dalam melakukan kajian kebijakan pengelolaan HL khususnya pemanfaatannya untuk penyadapan getah pinus adalah pola diskusi-diskusi yang intensif dan aktif terhadap pihak-pihak yang terlibat dalam penyadapan getah pinus (Focal Group Discussion). Untuk lebih jelasnya pola pikir tersebut dapat dilihat pada Gambar 1.

\section{B. Pengumpulan Data}

Data yang dikumpulkan meliputi data primer dan data sekunder yang diperoleh dari pengamatan langsung di lapangan baik berupa diskusi dan wawancara langsung dengan para pihak terkait dengan pemanfataan $\mathrm{HL}$ (Gambar 2) maupun dari pengumpulan bahan dan literatur serta laporan yang berkaitan dengan pengelolaan $\mathrm{HL}$ sebagai penghasil barang dan jasa lingkungan. Lokasi Penelitian dilakukan di areal Perum Perhutani Unit III Jawa Barat dan Banten. 


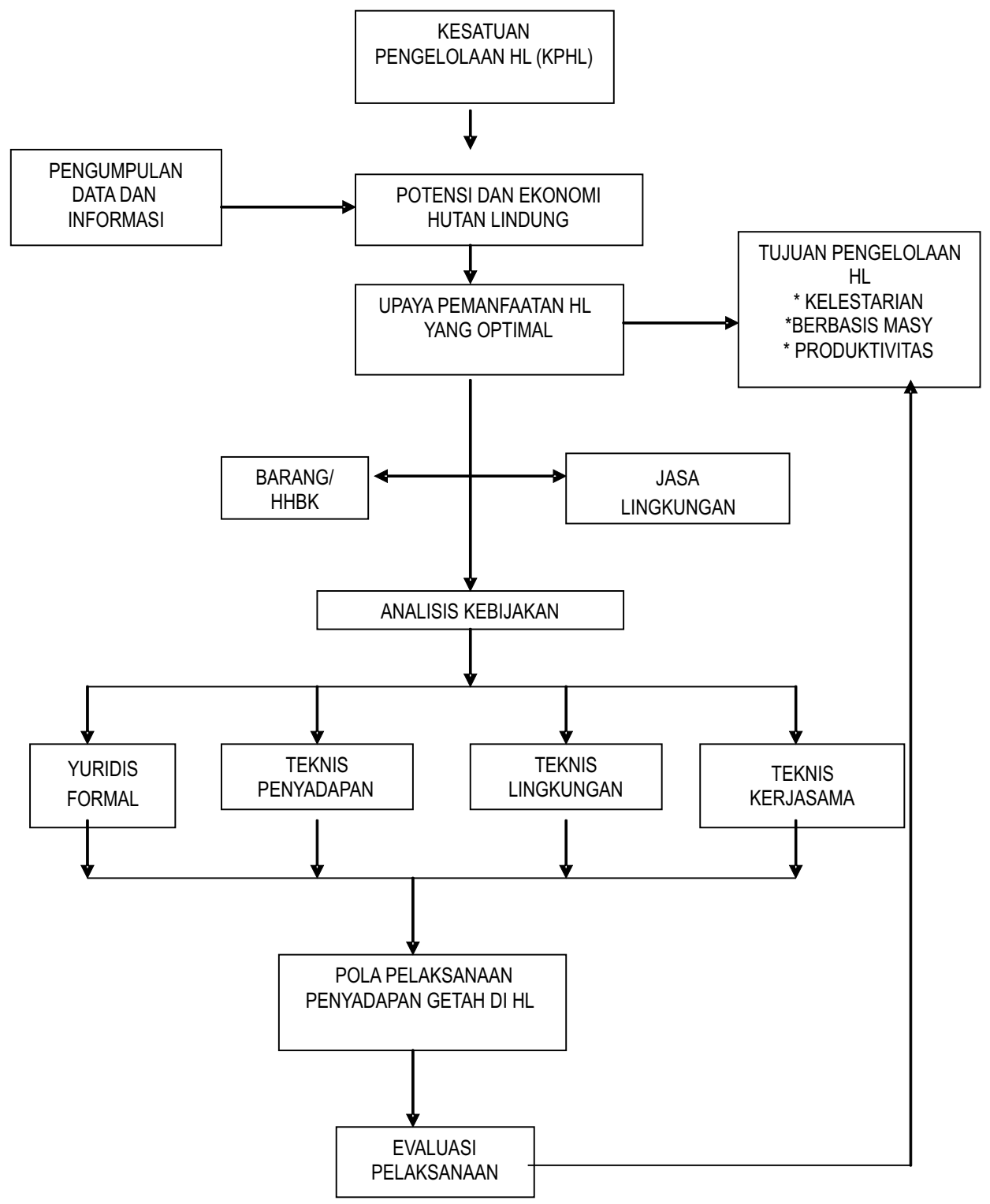

Gambar 1. Pola pikir yang digunakan dalam kajian kebijakan pengelolaan hutan lindung Figure 1. Framework used in the policy analysis on forest protection management 
Peninjauan lapangan untuk melihat lokasi tempat tumbuh pohon pinus yang dikelola Perhutani dilakukan pada: (1) Petak 49 a (Blok Cikole), RPH Lembang BKPH Bandung Utara, Wilayah Administratif Kabupaten Bandung, (2) Petak 24 a (Blok Cigendel), RPH Rancakalong BKPH Manglayang Timur KPH Sumedang, Wilayah Administratif Kabupaten Sumedang, (3) Petak 45 b (Blok Palintang), RPH Rancamanik BKPH Manglayang Barat KPH Bandung Utara, Wilayah Administratif Kabupaten Bandung, dan (4) Petak 3 b, RPH Rancakalong BKPH Manglayang Timur KPH Sumedang, Wilayah Administratif Kabupaten Sumedang.

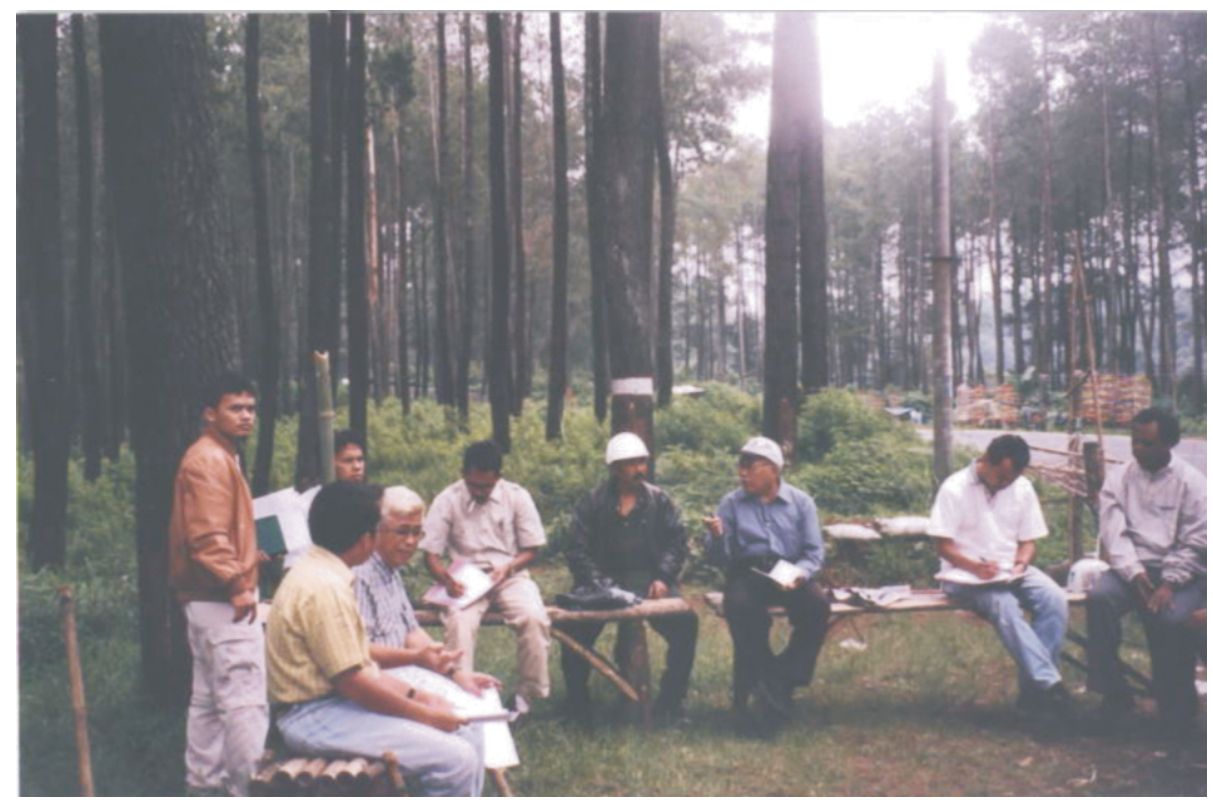

Gambar 2. Diskusi intensif antara anggota tim pengkajian dengan para pihak Figure 2. Intensive discussion among researchers with stakeholders

\section{Pengolahan Data}

Pengolahan data menggunakan metoda analisis kualitatif desktiptif dimana data dan informasi terkait dengan peraturan perundang-undangan, teknis penyadapan dan teknis konservasi tanah dan air dianalisa untuk menjawab kemungkinan penyadapan getah pinus di hutan lindung.

\section{HASIL DAN PEMBAHASAN}

\section{A. Luas Sadapan Getah Pinus Perum Perhutani Unit III}

Pohon pinus (Pinus merkusii et de Vries) merupakan jenis pohon lokal yang tumbuh secara alamiah di Provinsi Aceh (NAD) dan Sumatera Utara. Kemudian jenis pohon ini berhasil dikembangkan di daerah jawa dan Bali. Pinus ini tumbuh dengan baik pada lahan dengan ketinggian antara 200 - 1500 di atas permukaan laut (dpl) dan digunakan sebagai salah satu jenis pohon penghijauan yang ditanam hampir diseluruh pelosok Pulau Jawa (Soenardi, 1980). 
Saat ini luas areal sadapan getah pinus di areal Perum Perhutani Unit III Jawa Barat dan Banten (selanjutnya disebut Perhutani) selama lima tahun terakhir terus menerus mengalami penurunan sebagaimana terlihat pada Tabel 1. Tabel tersebut menunjukkan bahwa luas areal sadapan getah pinus menurun sangat signifikan dari luasan 20.942 ha (2000) menjadi 12.848 ha (2004) dengan laju sekitar 1.619 ha/tahun. Laju penurunan luas sadapan terbesar berada di KPH Garut, Sumedang, Bandung Selatan, Sukabumi, Majalengka, Tasikmalaya, Bandung Utara dan Bogor.

Tabel1. Luas sadapan getah pinus pada Perum Perhutani Unit III Jawa Barat dan Banten dalam 5 tahun terakhir (2000-2004)

Table 1. Total area of pine resin extraction at Perum Pehutani Unit III Jawa Barat and Banten for the last five years (2000-2004)

\begin{tabular}{|c|l|r|r|r|r|r|c|}
\hline \multirow{2}{*}{ No. } & \multicolumn{1}{|c|}{$\begin{array}{c}\text { Kesatuan } \\
\text { Pemangkuan Hutan }\end{array}$} & \multicolumn{6}{|c|}{ Luas Areal Sadapan (Ha) Dalam Tahun } \\
\cline { 3 - 8 } & & 2000 & 2001 & 2002 & 2003 & 2004 & $\begin{array}{c}\text { Perubahan } \\
\text { (ha/th) }\end{array}$ \\
\hline 1. & Bogor & 1.695 & 1.619 & 1.257 & 1.500 & 1.344 & -88 \\
\hline 2. & Sukabumi & 5.504 & 4.754 & 4.185 & 4.487 & 4.661 & -211 \\
\hline 3. & Cianjur & 761 & 751 & 742 & 723 & 751 & $-2,5$ \\
\hline 4. & Purwakarta & 460 & 409 & 380 & 393 & 361 & -25 \\
\hline 5. & Bandung Utara & 1.083 & 893 & 329 & 1.023 & 529 & $-138,5$ \\
\hline 6. & Bandung Selatan & 1.800 & 1.525 & 1.027 & 897 & 359 & -360 \\
\hline 7. & Garut & 3.157 & 2.584 & 2.202 & 2.230 & 500 & -664 \\
\hline 8. & Tasikmalaya & 1.049 & 1.137 & 894 & 1.646 & 230 & -205 \\
\hline 9. & Ciamis & 854 & 799 & 581 & 650 & 1.468 & $+153,5$ \\
\hline 10. & Kuningan & 1.074 & 1.070 & 1.627 & 1.776 & 1.683 & +152 \\
\hline 11. & Majalengka & 1.339 & 1.125 & 1.363 & 254 & 520 & -205 \\
\hline 12. & Sumedang & 2.616 & 2.408 & 1.783 & 1.877 & 441 & -544 \\
\hline & Jumlah & 20.942 & 19.704 & 16.370 & 17.456 & 12.848 & \\
\hline
\end{tabular}

Sumber (Source): Perhutani (2005).

\section{B. Kebijakan Umum (Peraturan Perundang-undangan)}

Secara umum kajian peraturan ini dilaksanakan untuk melihat peluang pemanfaatan $\mathrm{HL}$ untuk kegiatan penyadapan getah di kawasan hutan yang dikelola oleh Perhutani, sehingga aspek yang dikaji lebih diarahkan kepada upaya pencapaian tujuan kajian, seperti: (i) pengertian dan penetapan kriteria HL, (ii) bentuk-bentuk pemanfaatan $\mathrm{HL}$, (iii) persyaratan teknis penyadapan getah di HL, (iv) prosedur pengurusan ijin dan pemegang ijin penyadapan getah, dan (v) hak dan kewajiban pemegang ijin penyadapan getah.

Adapun peraturan perundangan yang digunakan dalam kajian ini adalah: (1) UU Nomor 41 Tahun 1999 tentang Kehutanan, (2) Peraturan Pemerintah (PP) Nomor 34 Tahun 2002 tentang Tata Hutan dan Penyusunan Rencana Pengelolaan, Pemanfaatan dan Penggunaan Kawasan Hutan, (3) PP Nomor 44 Tahun 2004 tentang Perencanaan Hutan, dan (5) PP Nomor 45 Tahun 2004 tentang Perlindungan Hutan.

\section{Pengertian dan penetapan kriteria hutan lindung}

Hutan lindung didefiniskan sebagai kawasan hutan yang mempunyai fungsi pokok sebagai perlindungan sistem penyanggaa kehidupan untuk mengatur tata air, mencegah banjir, mengendalikan erosi, mencegah intrusi air laut dan memelihara kesuburan tanah (UU No. 41/1999, Pasal 1). 


\section{Analisis Kedijakan Penged daan Hutan. .. . Subanud, Ngaloken Gintings, dan Suward Sumadwangsa}

Kreteria penetapan HL dijelaskan dalam PP No. 44/2004, Pasal 24: kawasan hutan dapat ditetapkan menjadi $\mathrm{HL}$, apabila memenuhi salah satu kriteria:

(1) kawasan hutan dengan faktor-faktor kelas lereng, jenis tanah dan intensitas hujan setelah masing-masing dikalikan dengan angka penimbang mempunyai jumlah nilai (skore) 175 (seratus tujuh puluh lima) atau lebih;

(2) kawasan hutan yang mempunyai lereng lapangan $40 \%$ (empat puluh per seratus) atau lebih;

(3) kawasan hutan yang berada pada ketinggian 2000 (dua ribu) meter atau lebih diatas permukaan laut;

(4) kawasan hutan yang mempunyai tanah sangat peka terhadap erosi dengan lereng lapangan lebih dari $15 \%$ (lima belas per seratus);

(5) kawasan hutan yang merupakan daerah resapan air;

(6) kawasan hutan yang merupakan daerah perlindungan pantai.

Berdasarkan kriteria penetapan HL tersebut, kebanyakan areal hutan produksi Perhutani yang berubah menjadi $\mathrm{HL}$ dikarenakan kawasan hutannya merupakan daerah resapan air.

\section{Bentuk-bentuk pemanfaatan $\mathrm{HL}$}

Secara umum pemanfaatan hutan dibatasi sebagai bentuk kegiatan: (i) pemanfaatan kawasan hutan, (ii) pemanfaatan jasa lingkungan, (iii) pemanfaatan hasil hutan kayu dan bukan kayu serta (iv) pemungutan hasil hutan kayu dan bukan kayu secara optimal, berkeadilan untuk kesejahteraan masyarakat dengan tetap menjaga kelestariannya (PP 34/2002, Pasal 1).

Sedangkan bentuk-bentuk pemanfaatan hutan pada $\mathrm{HL}$ terdiri dari tiga bidang pemanfaatan (UU 41/1999, Pasal 26; PP 34/2002, Pasal 19), yaitu: (1) pemanfaatan kawasan; (2) pemanfaatan jasa lingkungan; atau (3) pemungutan hasil hutan bukan kayu.

Pemungutan HHBK di HL dapat dilaksanakan dengan mengambil HHBK yang sudah ada dengan tidak merusak fungsi utama kawasan, seperti pengambilan rotan, madu, buah dan aneka hasil hutan lainnya atau perburuan satwa liar yang tidak dilindungi yang dilaksanakan secara tradisional (PP 34/2002, Pasal 21).

\section{Persyaratan teknis penyadapan getah di $\mathrm{HL}$}

Pemanfaatan hutan (dalam hal ini pemungutan HHBK) hanya dapat dilakukan pada blok pemanfaatan karena pembagian kawasan pada $\mathrm{HL}$ dibagi dalam 3 blok, yaitu blok perlindungan, blok pemanfaatan dan blok lainnya (PP 34/2002, Pasal 12).

Persyaratan teknis perlakuan atas pemungutan HHBK disesuaikan dengan lokasi dan atau jenis usaha yang diatur untuk: (i) tidak menebang pohon, (ii) tidak mengganggu kelestarian pohon yang dipungut, dan (iii) tidak menggunakan peralatan mekanis (PP 34/2002, Pasal 24).

Dengan demikian dapat disimpulkan bahwa kegiatan penyadapan getah pinus di HL masuk dalam bentuk kegiatan pemanfaatan hutan butir 3, yaitu pemungutan hasil hutan bukan kayu (HHBK) dan hanya diperbolehkan di blok pemanfaatan. Oleh karena itu perlu dicari informasi tentang kriteria dan standar penetapan blok-blok pada HL sehingga Perhutani dapat lebih pasti dan yakin tentang perbedaan antara blok perlindungan dan blok pemanfaatan sebagai antisipasi klaim ataupun tuntutan dari para pemangku kepentingan (stakeholders).

4. Pemegang ijin dan prosedur pengurusan ijin penyadapan getah di $\mathrm{HL}$

Berkaitan dengan subyek pemegang ijin pemungutan HHBK di HL ditetapkan dalam UU No. 41/1999, Pasal 27 dan PP No. 34/2002, Pasal 36 adalah perseorangan dan koperasi. Tata cara dan 
permohonan ijin dilakukan berdasarkan kewenangan pemberi ijin pada lokasi ijin tersebut dilaksanakan.

Ketentuan lainnya dari pengurusan ijin adalah (i) ijin tersebut tidak dapat diberikan dalam areal hutan yang telah dibebani ijin pemanfaatan hutan, (ii) ijin tidak dapat dipindah tangankan tanpa persetujuan tertulis pemberi ijin, dan (iii) areal yang telah dibebani ijin pemanfaatan tidak dapat dijadikan jaminan atau dijaminkan kepada pihak lain (PP 34/2002, Pasal 22). Jangka waktu ijin pemungutan HHBK diberikan paling lama 1 (satu) tahun dan dapat diperpanjang yang jangka waktunya berakhir sesuai dengan ketentuan dalam jumlah, jenis, dan lokasi tertentu yang ditetapkan dalam ijin (PP 34/2002, Pasal 23 dan Pasal 50).

\section{Hak dan kewajiban pemegang ijin penyadapan getah di $\mathrm{HL}$}

Hak dan kewajiban pemegang ijin pemungutan HHBK (penyadapan getah) di HL tidak ada penjelasannya sebagaimana terjadi pada ijin-ijin usaha pemanfaatan hutan, ijin usaha pemanfaatan kawasan, ijin usaha jasa lingkungan (UU 41/1999 Pasal 46 dan 47).

Perlindungan pada hutan hak dilakukan oleh pemegang hak dan untuk menangani pelaksanaan perlindungan hutan yang sebaik-baiknya, masyarakat diikut sertakan dalam upaya perlindungan hutan (UU 41/1999 Pasal 48). Perlindungan hutan yang menjadi kewenangan pemerintah dan atau pemerintah daerah di wilayah dan untuk kegiatan tertentu dapat dilimpahkan kepada BUMN yang bergerak di bidang kehutanan (PP 45/2004, Pasal 3).

\section{Kebijakan Teknis}

\section{Teknis penyadapan}

Secara umum ada 3 (tiga) metode penyadapan pinus yang meliputi: (i) sistem kowakan (quarre), (ii) sistem saluran (Indian System), dan Sistem Portugis (Portugese system) (Sumantri, 1991). Produktivitas hasil getah ketiga sistem tersebut telah diteliti oleh Endom (1989) dengan hasil sebagai berikut: (i) sistem kowakan berkisar antara 3-4 gram/pohon/hari, (ii) sistem saluran rata-rata sekitar $5 \mathrm{gram} /$ pohon/hari, dan (iii) sistem Portugis terlalu rendah yaitu sekitar 2,55 gram/pohon/hari.

Kemungkinan dari data produktivitas ketiga metode tersebut, Perhutani merekomendasikan 2 metode saja, yaitu metode koakan (quare methods) dan metoda bentuk V (sersan terbalik) sebagaimana pedomannya yang ditetapkan dalam Keputusan Direksi Perhutani Nomor 688/KPTS/DIR/1985 dan Nomor 879/KPTS/DIR/1992. Untuk lebih jelasnya gambaran tentang kedua sistem tersebut dapat dilihat pada Gambar 4 dan 5. 


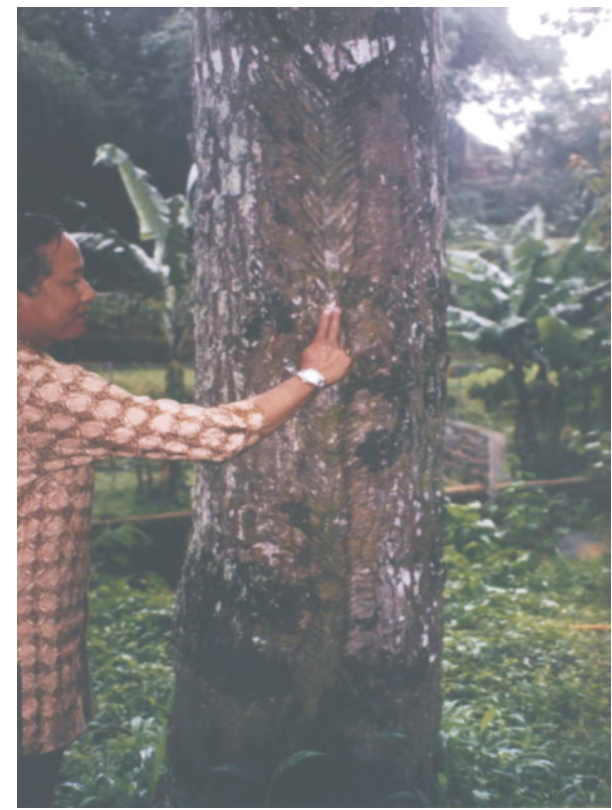

Gambar 4. Penyadapan pinus dengan sistem kowakan

Figure 4. Pine resin extraction with quarre method

(Sumber/source: Sumantri (1991)
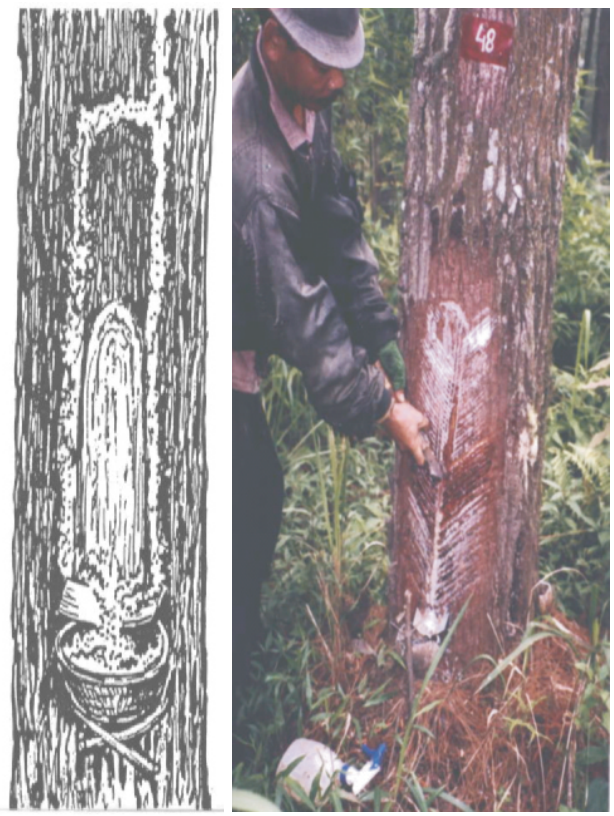

Gambar 5. Penyadapan pinus dengan sistem saluran

Figure 5. Pine resin extraction with riil method

Berdasarkan teori dan hasil pengamatan langsung di lapangan, tenyata metoda kowakan yang dilaksanakan Perhutani perlu pengawasan dan pengendalian di lapangan untuk menghindari kedalaman luka sadap (kowakan) yang akan mengakibatkan kayu tumbang. Temuan ini diperkuat dengan pernyataan Sumantri (1991) bahwa sistem kowakan yang dilaksanakan Perhutani menunjukkan hal-hal yang cukup rawan jika pengawasannya lemah karena ada kecenderungan penyadap membuat kowakan yang melebihi ukuran, terutama tingkat kedalaman kowakan yang besar sehingga merusak batang kayu. Kerusakan ini akan mengakibatkan pohon mudah tumbang saat terjadinya hujan lebat dan angin ribut. Oleh karena itu kepada Perhutani disarankan untuk menggunakan metode saluran (sersan terbalik) dalam kegiatan penyadapan getah pinus di HL karena metoda tersebut paling aman terhadap daya hidup pohon sehingga mempunyai peluang yang sangat kecil untuk membuat pohon roboh. Hal ini sejalan dengan penjelasan Sumantri (1991) bahwa sistem saluran diperkenalkan untuk mencari sistem penyadapan yang lebih baik dengan tujuan meningkatkan hasil dan tidak merusak pohon.

\section{Teknis lingkungan (konservasi tanah dan air)}

Seperti telah diuraikan bahwa perubahan hutan produksi ke HL karena kriteria daerah tersebut merupakan resapan air. Dalam artian kawasan hutan tersebut sebagai penampung air di 
musim hujan dan penyedia air di musim kemarau, sehingga dalam pemanfaatan kawasan $\mathrm{HL}$ tersebut perlu dipertimbangan kondisi dan situasi tanaman bawahnya.

Secara umum besarnya aliran permukaan (run off) dan laju erosi dari suatu wilayah ditentukan oleh beberapa faktor penting, diantaranya:

(1) Lereng lapangan: Semakin besar lereng suatu wilayah maka makin besar kemungkinan mendatangkan aliran permukaan yang besar. Makin besar aliran permukaan maka laju erosi juga semakin tinggi.

(2) Lapisan tajuk: Makin banyak tingkat lapisan tajuk (bertingkat-tingkat) maka makin kecil energi kinetik butir curah hujan dalam memukul dan memecahkan butir tanah sehingga pori tanah tepat stabil. Hal ini menyebabkan kemampuan infiltrasi tanah di bawah tegakan yang lapisan tajuknya bertingkat-tingkat menjadi stabil dan cenderung besar, sehingga aliran permukaan dan erosi menjadi kecil.

(3) Tanaman bawah: Tanaman ini dapat dipandang sebagai lapisan terbawah dari tajuk yang bertingkat. Tambah lebat tanaman bawah maka aliran permukaan dan erosi yang terdapat dibawahnya pasti kecil juga.

(4) Jenis Tanah: Jenis tanah yang gembur umumnya mempunyai sifat mudah terbawa aliran permukaan sehingga erosi menjadi besar.

(5) Curah Hujan: Daerah dengan intensitas curah hujannya ( $\mathrm{mm} / \mathrm{jam})$ besar, maka kemungkinan aliran permukaan dan erosinya juga besar.

(6) Serasah: Serasah mempunyai banyak peran dalam konservasi tanah dan air, seperti: (i) menahan pukulan butiran curah hujan sehingga partikel tanah tidak terpencar atau terganggu, (ii) kelembabannya lebih stabil sehingga pertumbuhan mikroorganisme di bawahnya menjadi lebih banyak, dan (iii) serasah yang terdekomposisi akan menjadi pupuk organik yang kemampuannya memegang air lebih besar. Hal ini tentunya akan meningkatkan daya infiltrasi tanah menjadi lebih besar dan erosi menjadi lebih kecil. Jika infiltrasi besar maka air yang jatuh di permukaan bumi menjadi lebih mudah dimanfaatkan karena fluktuasi debitnya menjadi kecil.

Peranan serasah yang demikian besar telah diteliti oleh Coster (1938) di Ciparai, Bandung Selatan di mana daerah yang serasahnya dihilangkan akan mendatangkan aliran permukaan 510 kali dan laju erosinya meningkat kurang lebih 5 kali. Temuan ini diperkuat oleh Sriyani, et al. (1977) yang membuktikan bahwa jika lantai tanaman kopi terus menerus dibersihkan maka erosi selama 4 bulan dapat mencapai 9,6 ton/ha. Namun jika lantai tanaman kopi tidak dibersihkan, maka erosinya hanya mencapai 1,4 ton/ha.

Hal lain yang juga perlu dipertimbangkan adalah daerah yang tanahnya tidak stabil dalam artian sangat mudah longsor, jika ada sedikit perlakuan yang tidak benar (misalnya air tergenang, terjadi aliran air yang deras karena salah membuat saluran air dan sebagainya). Tanah-tanah yang rawan longsor sebenarnya sudah dipetakan oleh Direktorat Geologi di Bandung dan dapat dicarikan data dan informasinya. Kondisi seperti ini perlu diinformasikan terlebih dahulu kepada Pemerintah daerah setempat sehingga jika terjadi bencana di waktu yang akan datang dapat dipahami karena daerahnya memang sangat rentan akan longsor.

Berdasarkan pertimbangan aspek konservasi tanah dan air, maka lokasi contoh penyadapan getah pinus di daerah Cikole, Palintang, dan Rancakalong tidak akan menimbulkan erosi yang besar kalau tegakan Pinusnya disadap dengan metoda rill. Namun yang perlu diperhatikan dalam pelaksanaannya nanti adalah pembuatan jalan setapak yang tidak memotong kontur. Jalan setapak sebaiknya dibuat mengikuti garis kontur dan kalaupun terpaksa memotong kontur disarankan kelerengan jalan setapak maksimal $15 \%$. 
AnalisisKedijakan Pengddaan Hutan. .. Subarudi, Ngaldken Gintings, dan Suward Sumadiwangsa

3. Teknis kerjasama (kemitraan)

Seiring dengan perkembangan pemerintahan (politik) dan penduduk (sosial, budaya dan ekonomi) yang terjadi sekarang, peluang untuk mendapatkan pekerjaan dan menambah penghasilan dari para mantan penyadap getah semakin kecil, sehingga hal ini dikhawatirkan akan menimbulkan kerawanan sosial dan pada akhirnya akan mengancam kelestarian dari pengelolaan hutan di Provinsi Jawa Barat dan Banten.

Keinginan Perhutani untuk kembali melakukan penyadapan getah pinus di HL perlu diwujudkan pelaksanaannya dalam rangka menjaga kelestarian hutan lindung dan meningkatkan kesejahteraan masyarakat. Hal ini sejalan dengan UU No. 41/1999, Pasal 3 yang menyatakan bahwa penyelenggaraan kehutanan bertujuan untuk sebesar-besarnya kemakmuran rakyat yang berkeadilan dan berkelanjutan dengan: (a) menjamin keberadaan hutan yang cukup, (b) mengoptimalkan aneka fungsi hutan untuk mencapai manfaat lingkungan, sosial, budaya dan ekonomi yang seimbang dan lestari, (c) meningkatkan kemampuan untuk mengembangkan kapasitas dan keberdayaan masyarakat secara partisipatif, berkeadilan dan berwawasan lingkungan sehingga mampu menciptakan ketahanan sosial dan ekonomi serta ketahanan terhadap akibat perubahan eksternal, dan (d) menjamin distribusi manfaat yang berkeadilan dan berkelanjutan.

Sebagaimana telah disebutkan bahwa pelaku penyadapan getah adalah perorangan dan koperasi di sekitar hutan. Pengertian perorangan adalah orang seorang anggota masyarakat setempat yang cakap bertindak menurut hukum dan Warga Negara Republik Indonesia. Sedangkan koperasi adalah badan usaha yang beranggotakan orang seorang atau badan hukum koperasi dengan melandaskan kegiatannya berdasarkan prinsip koperasi sekaligus sebagai gerakan ekonomi rakyat yang berdasarkan atas asas kekeluargaan (UU No. 34/2002, Pasal 1).

Untuk memudahkan pelaksanaan penyadapan getah di $\mathrm{HL}$, maka usaha koperasi dianggap paling tepat sebagai wadah komunikasi antar anggota masyarakat yang dtinggal di sekitar hutan sehingga Perhutani cukup berkomunikasi langsung dengan para pengurus koperasi tersebut. Jika keberadaan koperasi belum ada, maka Perhutani dapat memfasilitasi pembentukannya dengan mengundang pejabat dari kantor Departemen Koperasi setempat sebagai pihak yang berkompeten untuk melaksanakan pembentukan koperasi-koperasi di lingkungan masyarakat. Setelah koperasi terbentuk, maka Perhutani dalam menindak lanjuti dengan membuat aturan main yang jelas dan adil antara masyarakat dengan Perhutani dalam suatu pola kemitraan. Jika diperlukan dapat dibuat semacam Surat Perjanjian Kerja (SPK) yang sudah biasa dilakukan Perhutani dalam kegiatan berbasis bukan lahan dalam Pengelolaan Sumber daya Hutan Bersama Masyarakat (PHBM) di kawasan hutan jatinya sebagaimana tercantum dalam Keputusan Ketua Dewan Pengawas Perum Perhutani No. 136/KPTS/DIR/2001, tanggal 29 Maret 2001.

\section{KESIMPULAN DAN REKOMENDASI}

\section{A. Kesimpulan}

Penyadapan getah pinus di Hutan Lindung dapat dikatagorikan sebagai salah satu upaya pemanfaatan hutan dalam bentuk pemungutan hasil hutan bukan kayu (HHBK) oleh masyarakat setempat dengan binaan oleh Perhutani.

Dari segi yuridis formal, penyadapan getah pinus di HL diperkenankan dan dapat dilakukan hanya pada blok pemanfaatan dengan tidak melakukan penebangan pohon, tidak mengganggu kelestarian potensi pohon yang dipungut, dan tidak menggunakan peralatan mekanis (besar). 
J umal AnalisisKedijakan Kehutanan

Vd. 2 No. 2, Juli 2005: 101- 113

Dari segi teknis penyadapan, penyadapan getah pinus di HL hanya dapat dilakukan dengan metoda penyadapan sersan terbalik (rill method) yang secara teknis tidak akan menyebabkan pohon roboh/rebah sebagaimana yang terjadi dengan metoda koakan (quare method). Namun pengawasan perlu diperhatikan lebih intensif oleh mandor Perhutani agar bidang sadapan (sisi terbuka) pada batang pohon pinus hanya sebesar $40 \%$ dengan meninggalkan bidang yang tidak disadap $(60 \%)$ untuk upaya penyembuhan luka tersebut tertutup kembali. Selain itu jumlah dan konsentrasi bahan stimulan tidak berlebih agar pohon tidak menjadi mati.

Dari segi konservasi tanah dan air, penyadapan getah pinus di HL diperkenankan sepanjang tidak mengabaikan faktor-faktor penyebab terjadinya aliran permukaan dan erosi, seperti lereng lapangan, lapisan tajuk, tanaman bawah, jenis tanah, curah hujan, serasah dan daerah-daerah yang rawan longsor. Hal lainnya adalah pembuatan jalan setapak hendaknya harus mengikuti garis kontur untuk menghindari adanya aliran permukaan dan erosi di jalur jalan tersebut.

Dari segi teknis pelaksanaan, penyadapan getah pinus di HL dapat dilakukan oleh masyarakat atau koperasi. Hal ini tentunya dapat diwujudkan dalam kerangka PHBM dengan sistem bagi hasil yang proporsional antara Perhutani dengan masyarakat (60:40\%) karena Perhutani menanggung biaya pembelian zat stimulan untuk kegiatan penyadapan.

\section{B. Rekomendasi}

1. Penyadapan getah pinus di $\mathrm{HL}$ dapat diperkenankan dari segi yuridis, teknis penyadapan (metoda rill), dan teknis konservasi tanah dan air, terutama pada daerah-daerah yang ditinjau dan ditetapkan sebagai lokasi uji coba penyadapan rill di HL serta masuk kriteria blok pemanfaatan dalam $\mathrm{HL}$.

2. Dalam pelaksanaan penyadapan getah pinus di suatu areal sangat diperlukan untuk meninggalkan pohon tanpa sadap sebanyak 10 pohon/ha sebagai kontrol untuk melihat perbedaan tumbuh antara pohon yang disadap dan tidak disadap.

3. Monitoring dan evaluasi pelaksanaan kegiatan penyadapan getah pinus di HL perlu dilakukan secara efektif dan intensif untuk memastikan bahwa kegiatan tersebut tidak menyebabkan kematian atau merobohkan pohon dan tidak pula menyebabkan besarnya aliran permukaan dan erosi di sekitar lokasi penyadapan.

4. Untuk pelaksanaan penyadapan getah pinus di HL pada daerah-daerah lainnya perlu mempertimbangkan persyaratan teknis konservasi tanah dan air sebagai suatu langkah yang penting dan tepat.

\section{DAFTAR PUSTAKA}

Coster, C.H. 1938. Bovengronsche en erosie op Java. Tectona DLXXXI: 613-728.

Endom, W. 1989. Penyadapan Getah Pinus Dengan Sistem Portugis. Majalah Duta Rimba No. 107108/XV/1989. Perum Perhutani. Jakarta.

Perum Perhutani. 1985. Pedoman Penyadapan Getah Pinus Dengan Sistem Kowakan. SK Direksi Perhutani No. 688/KPTS/DIR/1985, Tanggal 8 Oktober 1985.

Perum Perhutani. 1992. Pedoman Penyadapan Getah Pinus Dengan Sistem Saluran (Metoda Rill). SK Direksi Perhutani No. 879/KPTS/DIR/1992, Tanggal 27 Agustus 1992. 
Analisis Kedjjakan Pengddaan Hutan. . . Subarudi, Ngaldken Gintings, dan Sumard Sumædiwangsa

Perum Perhutani. 2005. Kajian Teknis Penyadapan Getah Pinus di Hutan Lindung Dengan Sistem Saluran. Perum Pehutani Unit III Jawa Barat dan Banten. Januari 2005.

Soenardi, A. 1980. Pembinaan dan Pengembangan Potensi Produksi Hasil Hutan Non Kayu. Prosiding Diskusi Hasil Hutan Non kayu. Jakarta, 10-12 Juli 1980.

Sriyani, N., H. Suprapto, H. Susanto, A.T. Lubis dan Y. Oki. 1977. Wood population dynamics in Coffee Plantation Managed by Different Soil Conservation Techniques. Faculty of Agriculture, University Lampung and Faculty of Environmental Science and Technology Okayama University, Japan.

Subarudi, N. Adi, B. Wiyono and D.S. Sukardi. 2001. Statistical Data Collection and Analysis on Non Wood Forest Products in Indonesia. Paper Submitted to Food and Agriculture Organization (FAO).

Sumantri, I. 1991. Perbaikan sistem penyadapan getah pinus untuk meningkatkan hasil getah. Jurnal Penelitian dan Pengembangan Kehutanan 7 (2): 21-25. Badan Litbang Kehutanan. Jakarta.

Sumantri, I., dan W. Endom. 1989. Penyadapan getah pinus merkusii dengan menggunakan beberapa pola sadap dan tingkat konsentrasi zat perangsang. Jurnal Penelitian Hasil Hutan 6 (3): 152-159. Puslitbang Hasil Hutan. Bogor.

Suryamiharja, S., dan Buharman. 1986. Hasil hutan non kayu di Indonesia. Sylvatropika 1 (1):3-5. Badan Litbang Kehutanan. Jakarta

Subarudi, D. Sukadri, N. Adi and B. Wiyono. 2001. Statistical data collection and analysis on nonwood forest products in Indonesia. Paper submitted to FAO. Unpublished. 